\title{
THE APPLICATION OF GEOMETRIC PROPORTION AND COMPOSITION THEORY TO THE BNI 46 JAKARTA BUILDING BY SILABAN
}

\author{
${ }^{1}$ Dewanti Ratnasarira. ${ }^{2}$ Caecilia S. Wijayaputri, ST., MT \\ ${ }^{1}$ Student in the Bachelor's (S-1) Study Program in Architecture \\ at Parahyangan Catholic University \\ 2 Senior lecturer in the Bachelor's (S-1) Study Program in Architecture \\ at Parahyangan Catholic University
}

\begin{abstract}
In terms of history, proportion, composition and geometry have been applied as design elements since long ago, way before the era of modern architecture. The existence of these three elements enables numerous variations and produces freedom of expression. Unfortunately, in current design processes, these visual principles are often overlooked. In fact, they play a role as one of the indicators of aesthetics of a building, as well as exerting influence on human perception in capturing and perceiving a given space. The purpose of this research is to study the application of proportion and composition principles to one of the creations of the Indonesian modern architect Frederich Silaban. The BNI 46 Building design by Silaban acts as the research object, displaying a façade which is crammed with modern thoughts, different on each side but remaining harmonious and visually attractive. The theory of proportion, composition, geometry and structuring principles provide the basis for analyzing the existing object. This research uses the descriptive analytical method with the qualitative approach to data collection of the research object. The next step is the vertical and horizontal analysis of the building enclosure in relation to the implementation of geometric proportion and composition principles in the building. This research is expected to be beneficial in terms of enriching the knowledge and study of geometric proportion and proportion in architecture, adding to the consideration of implementing visual principles for professionals, as well as adding to the archive/portfolio concerning Silaban as one of Indonesia's pioneering modern architects.
\end{abstract}

\section{PENERAPAN TEORI PROPORSI DAN KOMPOSISI GEOMETRIS PADA GEDUNG BNI 46 JAKARTA KARYA SILABAN}

\author{
${ }^{1}$ Dewanti Ratnasarira. ${ }^{2}$ Caecilia S. Wijayaputri, ST., MT \\ ${ }^{2}$ Mahasiswi S1 Program Studi Arsitektur Universitas Katolik Parahyangan \\ ${ }^{2}$ Dosen Pembimbing S1 Program Studi Arsitektur Universitas Katolik Parahyangan
}

\begin{abstract}
Abstrak- Dalam sejarahnya proporsi, komposisi dan geometri sudah diterapkan sebagai elemen perancangan sejak jaman dahulu, bahkan jauh sebelum era arsitektur modern. Kehadiran ketiga unsur tersebut memungkinkan variasi yang beragam dan menghasilkan suatu kebebasan berekspresi. Namun kini justru dalam suatu proses perancangan, prinsip-prinsip visual tersebut seringkali terabaikan. Padahal pada kenyataannya prinsip-prinsip tersebut berperan sebagai salah satu alat ukur nilai estetis pada suatu bangunan, serta mempengaruhi persepsi manusia dalam menangkap dan merasakan suatu ruang. Tujuan penelitian ini adalah untuk mengkaji penerapan prinsip proporsi dan komposisi pada salah satu karya arsitek modern Indonesia, Frederich Silaban. Gedung BNI 46 Jakarta karya Silaban, sebagai objek studi, menampilkan fasad yang kental akan pemikiran modern, sangat beragam pada setiap sisinya namun tetap harmonis dan menarik secara visual. Teori mengenai proporsi, komposisi, geometri, dan prinsip penataan menjadi dasar dalam menganalisis objek yang ada. Penelitian ini menggunakan metoda deskriptif dan analitif dengan pendekatan secara kualitatif dalam pengumpulan data terkait objek studi. Selanjutnya elemen pelingkup bangunan secara vertikal horizontal bangunan dikaji dan di analisis terkait dengan penerapan prinsip proporsi dan komposisi geometris pada bangunan.Penelitian ini diharapkan dapat
\end{abstract}

${ }^{1}$ Corresponding Author: dewanti.ratnasarira@gmail.com 
bermanfaat untuk memperkaya pengetahuan dan kajian akan proporsi dan komposisi geometris dalam arsitektur, menambah pertimbangan akan penerapan prinsip-prinsip visual bagi para profesional, serta menambah arsip karya-karya F. Silaban sebagai salah satu arsitek modern awal di Indonesia.

Kata-kata kunci: proporsi, komposisi, geometri, Silaban

\section{PENDAHULUAN}

Periode pasca kemerdekaan (1945-1970) merupakan era dimana muncul pandanganpandangan baru akan arsitektur serta menandai dimulainya pemikiran arsitektur modern di Indonesia. Salah satu figur yang paling berperan dalam era pembangunan tersebut adalah arsitek Frederich Silaban. Karya-karyanya kental akan pemikiran arsitektur modern dimana ekspresi bentuk mencerminkan fungsi. Salah satu ciri khas pada rancangannya adalah tampilan fasad yang kaya akan bentuk geometris dan menarik secara visual.

Geometri dalam suatu rancangan tidak hanya dilihat sebagai alat ukur estetis namun juga berhubungan dengan proporsi dan komposisi secara keseluruhan. Ketiganya merupakan prinsip-prinsip visual yang dapat digunakan untuk menilai suatu bangunan secara estetis, namun dalam suatu proses perancangan seringkali terabaikan. Padahal geometri, proporsi dan komposisi merupakan elemen dasar dalam menciptakan suatu tatanan yang harmonis dan selaras, serta dapat mempengaruhi persepsi visual pengamat dan penggunanya dalam merasakan suatu ruang.

Gedung BNI 46 di Jalan Lada, Jakarta yang dibangun pada tahun 1960 adalah salah satu karya Silaban yang dijadikan objek studi dalam penelitian ini. Fasad bangunan dikomposisikan secara harmonis menggunakan bentuk geometris sederhana dengan penggunaan bentuk-bentuk geometris yang sangat beragam. Dengan suatu pola tertentu, setiap sisi bangunan dirancang dengan komposisi bentuk geometris yang berbeda-beda dan menghasilkan suatu kesatuan namun harmonis dan indah secara estetis. Dengan keanekaragaman elemen dan prinsip yang terdapat di dalamnya, keselarasan antar unsur tatanan dengan elemen pelingkup dan ruang di dalamnya serta kualitas estetis bangunan menjadi menarik untuk ditelaah.

Penelitian yang dilakukan menggunakan prinsip-prinsip visual proporsi dan komposisi geometris sebagai acuan untuk meninjau bagaimana kedua prinsip tersebut di terapkan pada ruang dan fasad bangunan, serta untuk menemukan pola hubungan yang terbentuk pada komposisi geometris ruang dan fasad bangunan. Pada akhirnya, diharapkan penelitian ini dapat menjadi pertimbangan atau referensi dalam suatu proses perancangan dengan menerapkan prinsip-prinsip visual serta mengkaji hubungan prinsip-prinsip tersebut dengan prinsip penataan bangunan.

Berdasarkan latar belakang dan rumusan masalah dari penelitian ini, maka tujuan utama dari penelitian adalah untuk mengidentifikasi penerapan proporsi pada komposisi ruang dan fasad Gedung BNI 46 Jalan Lada, mengkaji pola hubungan yang terbentuk pada komposisi geometris ruang dan fasad Jalan Lada, mengkaji pemahaman proporsi, komposisi dan geometri dalam arsitektur, serta mengkaji prinsip tatanan bentuk pada Gedung BNI 46 Jalan Lada.

Penelitian ini menggunakan pendekatan metoda kualitatif-deskriptif dengan mengaitkan data faktual lapangan yang bersifat kualitatif dengan hasil studi literatur dengan pemaparan berupa deskripsi. Dalam metoda kualitatif, penelitian dilaksanakan langsung pada objek guna memperoleh data-data yang diperlukan dalam proses penelitian untuk kemudian divisualisasikan secara 3 dimensi.

Sementara analisis deskriptif dimulai dengan membuat deskripsi atau gambaran secara sistematis, faktual dan akurat berdasarkan fakta, sifat dan hubungan antara fenomena yang menjadi titik berangkat penelitian. Data kemudian dikaitkan, ditelaah kemudian dianalisis 
dengan tujuan akhir berupa kajian pada penerapan teori proporsi dan komposisi geometris dengan batasan objek studi berupa elemen pelingkup ruang dan fasad bangunan.

Analisis dimulai dengan pembahasan pada proporsi kemudian komposisi pada setiap segmen fasad, ditinjau per lapisan elemen pelingkup bangunan. Digunakan juga pendekatan interpretatif dimana analisis dilakukan dengan mencocokan data faktual yang diperoleh di lapangan dengan teori yang terkait.

Selanjutnya dilakukan analisis hubungan antara proporsi dan komposisi geometris dengan prinsip penataan bangunan Gedung BNI 46 Jakarta. Hasil analisis kemudian membantu menguraikan benang merah dari keseluruhan elemen pelingkup hingga terbentuknya suatu tatanan yang harmonis.

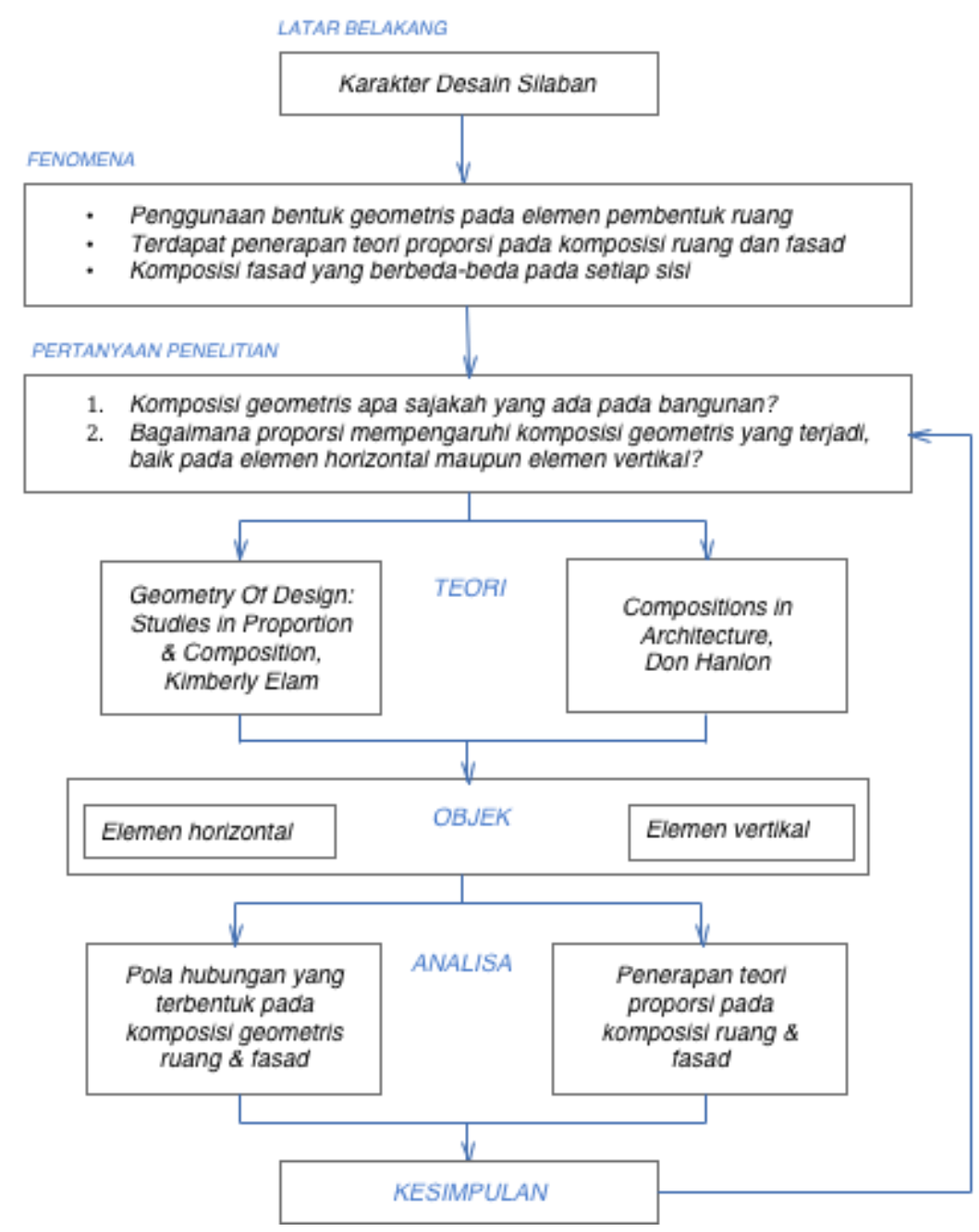

Figur 1.

\section{KAJIAN TEORI}

\subsection{KOMPOSISI GEOMETRIS: KAJIAN TEORITIK}

Komposisi geoetris terbentuk akibat adanya proporsi, komposisi, dan unsur lainnya yang terbentuk oleh elemen-elemen pembentuk milik bangunan 


\section{1.a. Komposisi}

Don Hanlon dalam "Compositions in Architecture"(2009), mengutarakan bahwa komposisi adalah kumpulan pola dengan kompleksitas beragam yang tersusun satu sama lain. Pada dasarnya, segala aspek pada bangunan dapat dipandang sebagai suatu pola yang terbentuk dari elemen-elemen bangunan, yang saling berhubungan secara dimensional untuk menciptakan suatu susunan atas skala dan kompleksitas yang berkesinambungan. Don Hanlon, juga menyebutkan terdapat lima sifat formal komposisi: (1) Bilangan / Number (2) Geometri / Geometry (3) Proporsi / Proportion (4) Hirarki / Hierarchy (5) Orientasi / Orientation.

Bentuk dapat diistilahkan sebagai penampilan eksterior yang dapat dikenali. Hubungan antara bentuk geometris merupakan bahasa dalam membaca suatu pola (Don Hanlon, 2009). Kesamaan dalam penggunaan geometri dapat melahirkan suatu kontinuitas dan kesatuan.

Lapisan pada bangunan terdiri atas massa atau pun ruang, memungkinkan terjadinya penyaringan panas, angin, suara, hingga intergrasi antar fungsi dalam bangunan. Lapisan memungkinkan jaringan untuk bekerja dan terintegrasi sesuai fungsi. Hal tersebut dapat dikonsepkan baik secara horizontal maupun vertikal dalam tampak dan potongan.

\section{1.b. Proporsi}

Proporsi merupakan salah satu komponen penting dalam menciptakan suasana yang harmonis di antara unsur-unsurnya pada konstruksi visual. Perbandingan antar masing-masing sisi garis yang membentuk bidang maupun ruang dalam keseluruhan gugus bangunan merupakan prinsip proporsi. Euclid berpendapat bahwa rasio merupakan perbandingan kuantitatif dari dua hal yang serupa atau hampir sama. Sementara itu, proporsi lebih mendasarkan pada 'keseimbangan' dari rasio tersebut.

Golden Section

Golden Section dapat didefinisikan secara geometris sebagai sebuah garis yang terbagi sedemikian rupa di mana garis yang lebih kecil selalu dibandingkan dengan garis yang lebih besar. Hal tersebut dapat ditunjukan secara aljabar dengan membandingkan dua rasio: $\mathrm{a} / \mathrm{b}=\mathrm{b} /(\mathrm{a}+\mathrm{b})$

Golden Section digunakan sebagai pendekatan dalam menemukan proporsi yang ideal melalui perbandingan rasio dari bentuk-bentuk geometris dalam arsitektur. Proporsi yang dihasilkan dianggap bentuk yang paling indah. Borissavlievitch mengatakan bahwa proporsi Golden Section menghadirkan keseimbangan antar dua bagian yang asimetri dan tidak sebangun. Hal ini digambarkan dengan rasio yang sama atau mendekati angka $1.618033988749895 \ldots$.

13 8

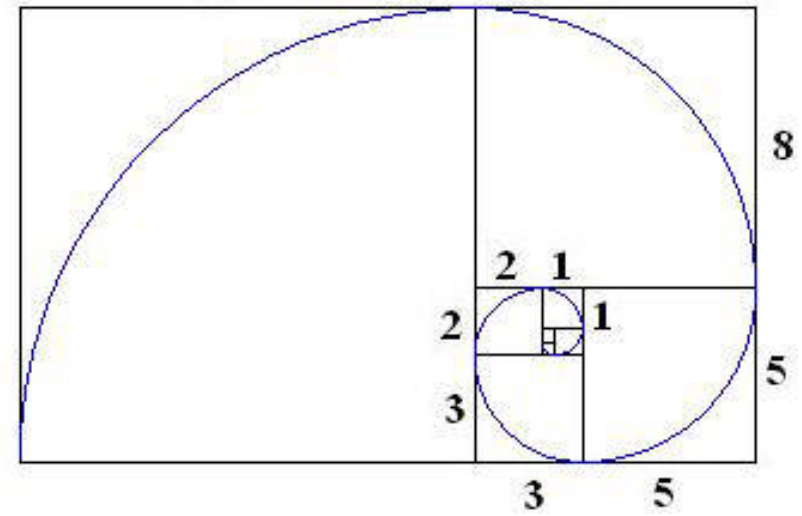

Figur 1. Rasio Golden Section 


\section{Root Rectangles}

Root rectangles merupakan ilmu turunan dari Golden Section. Bermula dari sebuah persegi panjang yang dinamis yang diperpanjang menggunakan serangkaian busur dan cross point untuk menghasilkan sosok bentuk yang diinginkan. Hasil dari proses tersebut dapat menghasilkan persegi panjang emas (1: 1.618 ...), proporsi $2 / 3$ persegi panjang, proporsi ganda persegi $(1 / 2)$ ataupun akar persegi panjang $(1: \sqrt{\varphi}, 1: \sqrt{ } 2,1: \sqrt{3}, 1: \sqrt{5}$, dll). Disebut simetri dinamis, berarti bahwa aspek rasio antara tinggi dan lebar adalah nilai yang dikhususkan dalam simetri dinamis dan sistem proporsi secara keseluruhan.

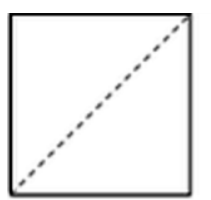

square $=1$
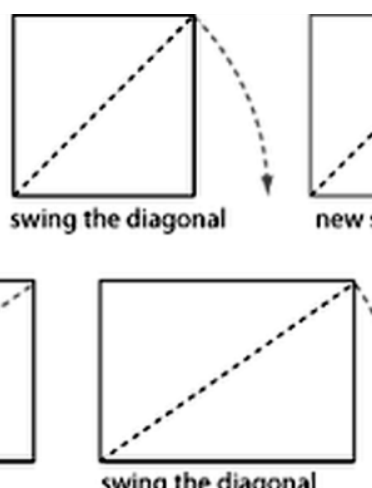

swing the diagonal
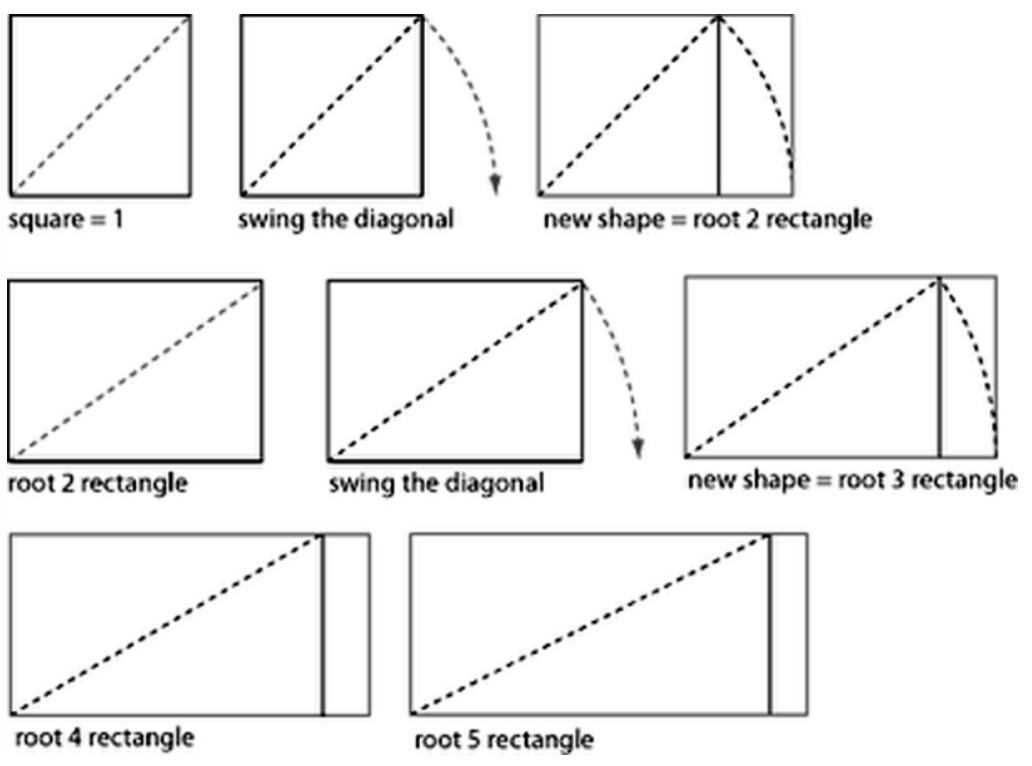

Figur 2. Metode perolehan proporsi Root Rectangles

\subsection{ORDERING PRINCIPLES}

Aktivitas sendiri dapat diartikan sebagai sesuatu yang dilakukan atau kegiatan-kegiatan yang terjadi, baik secara fisik maupun non-fisik. Menurut Jan Gehl, aktivitas dapat dikategorikan menjadi tiga, yaitu:

(1) Sumbu

Sumbu dapat diartikan sebagai suatu garis maya yang terbentuk oleh dua buah titik. Bentuk dan ruang yang membentuknya dapat diatur secara teratur atau pun tidak. Sumbu menuntut adanya keseimbangan pada tatanan dan harus diakhiri oleh sebuah bentuk atau ruang yang jelas pada setiap ujungnya. Unsur pengakhiran suatu sumbu dapat memberikan dan menerima perhatian visual.

Simetri

Simetri dapat diartikan sebagai distribusi dan susunan seimbang dari setiap bentuk dan ruang yang sama pada sisi berlawanan terhadap suatu garis atau bidang, atau pun terhadap titik pusat atau sumbu. Kondisi simetris menuntut susunan yang seimbang dari pola bentuk dan ruang.

Hirarki

Hirarki merupakan penekanan kepentingan atau keutamaan suatu bentuk berdasarkan ukuran, wujud, atau penempatan yang relatif terhadap bentuk atau ruang lain dari suatu organisasi. Dalam suatu komposisi arsitektur, sangat memungkinkan terdapat lebih dari satu unsur yang dominan. Akan tetapi, apa bila semua unsur ditonjolkan, maka tidak ada satupun yang dominan. 
(4)

Irama

Irama merupakan suatu pergerakan yang menyatukan, berupa pengulangan berpola atau pergantian unsur dalam bentuk yang sama atau dimodifikasi. Bentuk pengulangan paling sederhana adalah suatu pola linear dari unsur-unsur kelebihan.

(5)

Datum

Garis, bidang, atau volume dengan kesinambungan dan keteraturan yang berguna untuk mengumpulkan, mengukur, dan organisir suatu pola bentuk dan ruang dapat disebut dengan datum. Sebuah datum harus memiliki ukuran, penutup, serta keteraturan yang cukup agar tampak sebagai suatu figur yang merangkup unsur lainnya.

(6) Transformasi

Konsep arsitektur, struktur, atau organisasi dapat diubah melalui manipulasi dan mutasi dalam menanggapii suatu kondisi spesifik tanpa kehilangan identitas dapat kita sebut dengan transformasi.

\section{ANALISA}

\subsection{ARSITEKTUR GEDUNG BNI 46 JAKARTA}

Gedung BNI 46 Jakarta merupakan perencanaan pertama Silaban yang terbangun menggunakan atap datar. Beberapa ciri khas rancangan Silaban dapat ditemukan pada bangunan, seperti adanya koridor terbuka, penggunaan brise-soleil pada tampak, irama pengulangan struktur pada dasar bangunan, dan lainnya.

Rancangan bangunan ini semulanya diperuntukan bagi Bank Indonesia. Akan tetapi, Bank Indonesia ditempatkan pada karya Silaban lainnya di Jalan Thamrin. Pada awalnya gedung BNI 46 digunakan oleh masyarakat untuk penukaran valuta asing dan kegiatan transaksi lainnya.

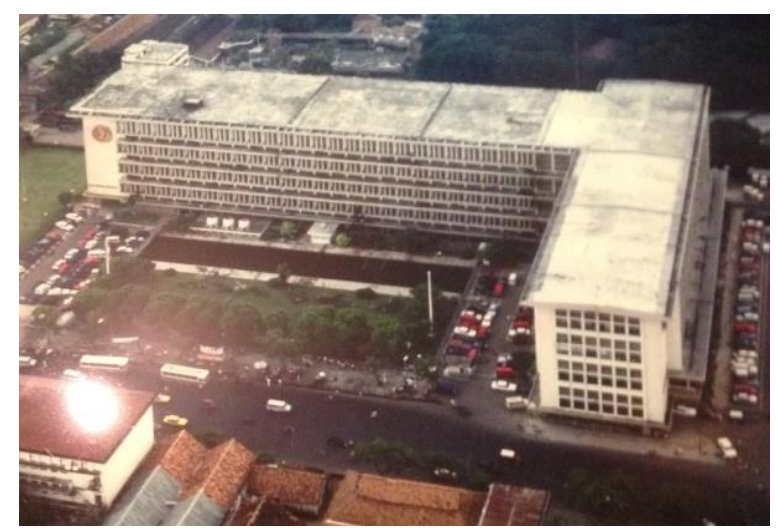

Figur 3. Gedung BNI 46 tahun 1960an

\section{1.a. Data Umum Gedung BNI 46}

Gedung BNI 46 merupakan salah satu karya Silaban dengan data sebagai berikut:

Nama : : Gedung BNI 46 Jakarta

Lokasi : Jalan Lada No. 1, Jakarta Barat, DKI Jakarta 11110

Dibangun : 1960

Diresmikan : 1962

Arsitek :Frederich Silaban 
Objek studi terletak di kawasan Kota Tua Jakarta. Berawal sebagai pusat perdagangan benua Asia, kawasan ini kini dilestarikan dan dalam tahap pengembangan untuk sepenuhnya dijadikan kawasan wisata. Kawasan di sekitar bangunan dulunya didominasi oleh fungsi-fungsi pemerintahan dan jasa. Namun, kini kawasan Kota Tua telah dialihkan sebagai kawasan wisata yang mengalami beberapa pengalihan fungsi.

\section{1.b. Anatomi Bangunan}

Gedung BNI 46 Jakarta memiliki 4 lantai dengan luas bangunan kurang lebih 5000 meter persegi. Wujudnya merupakan satu massa besar berbentuk L yang membentuk suatu inner court pada sisi Jalan Lada. Dari Fasadnya, bangunan memiliki 6 fasad yang berbeda sesuai dengan orientasinya dengan modul proporsi dan komposisi yang berbeda-beda.

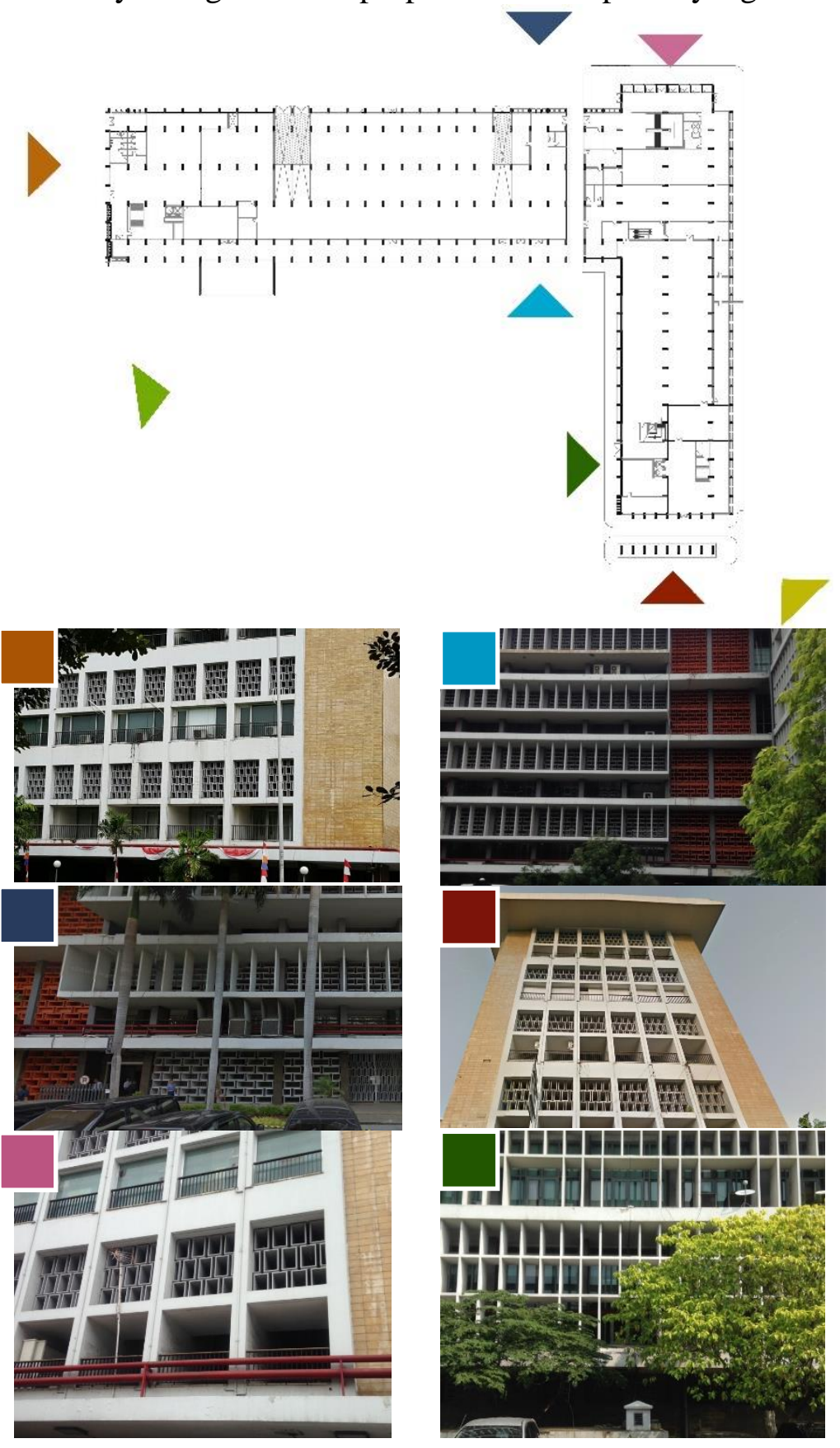



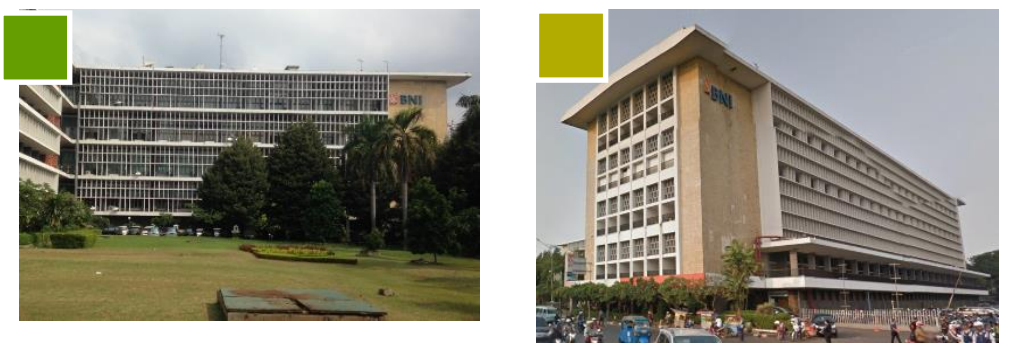

Figur 4. Fasad bangunan

Bangunan terdiri dari elemen penyusun kepala (atap), badan, serta kaki. Massa berbentuk solid dan menyatu terlihat kokoh karena dukungan material dan bentuk kaku yang kuat.

Lahan yang ditempati bangunan tersebut memiliki empat sisi muka yang berhadapan langsung dengan jalan. Akses utama dari lahan terdapat pada Jalan Lada yang berada di sisi Barat. Akan tetapi, peralihan fungsi dan kawasan membuat akses utama menuju tapak dipindah ke Jalan Lada Dalam yang berada di sisi timur lahan.

\section{1.c. Konsep dan Karya Fisik Frederich Silaban}

Ekspresi khas yang biasa diterapkan oleh Silaban ditandai dengan pemanfaatan brisesoleil pada muka bangunan. Belia terpengaruhi oleh gerakan Regionalist di Amerika Lain yang dipelopori oleh Le Corbusier dan Oscar Niemeyer yang diawali pada tahun 1930-an dengan mengambil tema tropis. Brise-soleil sebagai ciri khasnya berkembang dan digunakan pada bangunan-bangunan tropis.

Proporsi merupakan unsur pembentuk ekspresi yang menjadi penting dalam proses perancangan. Tinjauan proporsi Silaban bertolak dar pengertian dasar proporsi dan faktor pembentuknya. Proporsi pada bentuk bangunan silaban juga berkaitan erat dengan gaya arsitektur modern yang diantunya, menghasilkan bentuk-bentuk sederhana, lugas, tegas, serta dominan dengan bentuk persegi. Pengakhiran secara vertikal dan horizontal sangat terlihat dalam karya-karya Silaban.

Karya Silaban mencakup kompisisi fungsi, estetika, dan hubungan massa dengan tapak. Secara fungsi, karya silaban berkesan monumental. Karyanya juga menunjukan komposisi yang dominan atap dengan maksud menunjukan pentingnya atap pada bangunan tropis. Begitu juga dominasi elemen vertikal dan horizontal yang terbentuk oleh struktur.

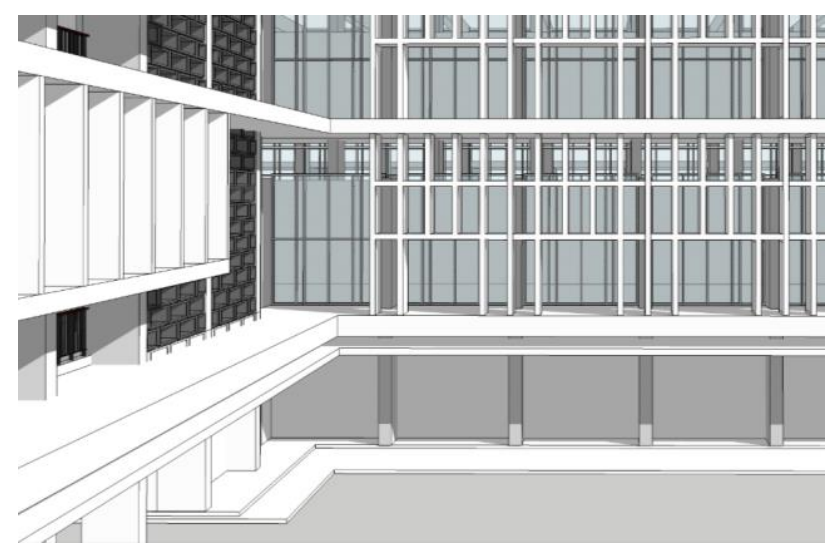

Figur 5. Fasad Gedung BNI 46 
Setiap sudutnya diolah dengan penyelesaian bentuk yang serupa, menjadikan elemen tersebut sebagai ciri khas dalam rancangan Silaban. Penyelesaian tersebut juga menjadi elemen yang menyatukan keseluruhan fasad, membentuk suatu komposisi yang harmonis.

\subsection{ANALISIS}

Analisis dibagi menjadi dua bagian yaitu pembahasan proporsi dan komposisi pada setiap segmen fasad bangunan yang telah dibagi menjadi 5 kategori, yaitu segmen fasad A-A', B-B', C, D dan E.

\section{2.a. Proporsi}

Analisis proporsi dilakukan pada setiap elemen pelingkup ruang yang membentuk lapisan secara horizontal. Ditemukan beberapa varian proporsi yang mendefinisikan bentuk fasad dan ruang pada bangunan:

Tabel 1.

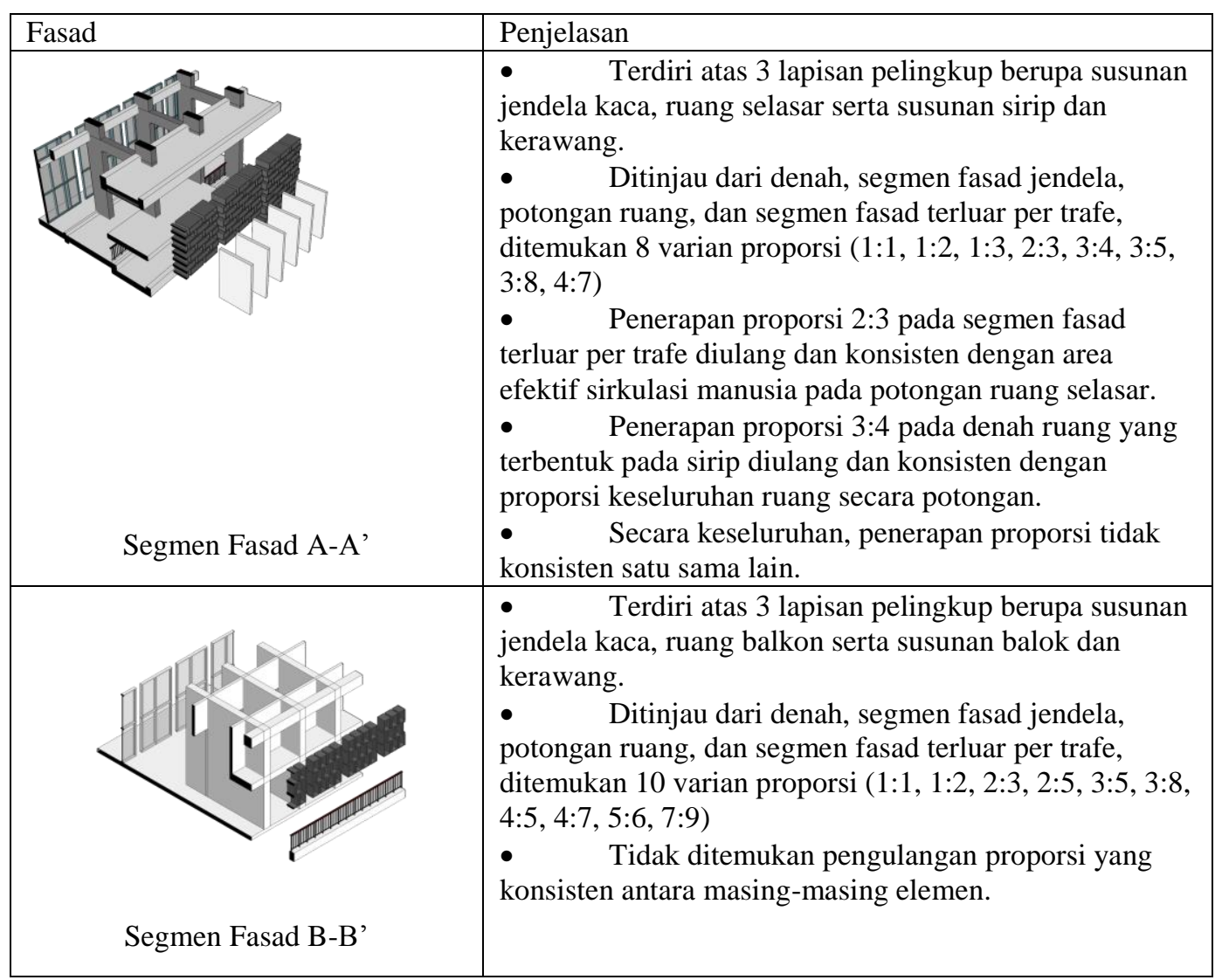




\begin{tabular}{|c|c|}
\hline Segmen Fasad C & $\begin{array}{l}\text { - Terdiri atas } 2 \text { lapisan pelingkup berupa susunan } \\
\text { jendela kaca dan sirip. } \\
\text { - } \quad \text { Ditinjau dari segmen fasad jendela dan segmen } \\
\text { fasad sirip terluar per trafe, ditemukan } 9 \text { varian proporsi: } \\
(1: 1,1: 2,1: 3,2: 3,2: 5,3: 5,3: 8,4: 7,5: 8) \\
\text { - Ditemukan penerapan Golden Section (1.618) } \\
\text { pada salah satu tipe modul sirip, pada tinggi modul grid } \\
\text { dan lebar antar kolom }(6.40: 4.00=1.6) \text { serta pada salah } \\
\text { satu sirip horizontal (4.00:2.40=1.67). } \\
\text { - } \quad \text { Penerapan proporsi } 1: 2 \text { dan } 2: 5 \text { diulang pada } \\
\text { segmen modul sirip pertama dan kedua } \\
\text { - } \quad \text { Proporsi } 5: 8 \text { secara konsisten digunakan pada } \\
\text { keseluruhan proporsi kedua pola modul sirip. } \\
\text { - } \quad \text { Secara keseluruhan, penerapan proporsi tidak } \\
\text { konsisten satu sama lain. }\end{array}$ \\
\hline Segmen Fasad D & $\begin{array}{l}\text { Terdiri atas } 2 \text { lapisan pelingkup berupa susunan } \\
\text { jendela kaca dan sirip. } \\
\text { f } \quad \text { Ditinjau dari segmen fasad jendela dan segmen } \\
\text { fasad sirip terluar per trafe, ditemukan } 9 \text { varian proporsi } \\
(1: 1,1: 2,1: 3,2: 3,2: 5,3: 5,3: 8,4: 7,5: 8) \\
\text { Penerapan proporsi } 1: 1,1: 3 \text { dan } 3: 5 \text { pada modul } \\
\text { sirip pertama diulang dan konsisten pada modul sirip } \\
\text { pola kedua. } \\
\text { - Secara keseluruhan, penerapan proporsi tidak } \\
\text { konsisten satu sama lain. }\end{array}$ \\
\hline & $\begin{array}{l}\text { - Terdiri atas } 3 \text { lapisan pelingkup berupa susunan } \\
\text { jendela kaca, ruang balkon serta susunan balok dan } \\
\text { kerawang. } \\
\text { - } \quad \text { Ditinjau dari denah, segmen fasad jendela, } \\
\text { potongan ruang, dan segmen fasad terluar per trafe, } \\
\text { ditemukan } 11 \text { varian proporsi: }(1: 1,1: 2,1 ; 3,2: 3,2: 5 \text {, } \\
\text { 3:5, 3;8, 4:7, 5:6, 5;8, 7:9) } \\
\text { - Tidak ditemukan pengulangan proporsi yang } \\
\text { konsisten antara masing-masing elemen. }\end{array}$ \\
\hline
\end{tabular}

Pada fasad C, ditemukan penerapan Golden Section pada salah satu tipe modul sirip. Dapat dikatakan bahwa penerapan tersebut tidaklah secara sengaja karena Golden Section dapat hadir secara alami.

Secara keseluruhan, ditemukan 14 varian proporsi dan beberapa pengulangan varian antar beberapa bagian (denah, tampak, potongan) maupun antar beberapa segmen fasad. Namun tidak ditemukan suatu pola penerapan proporsi yang konsisten.

\section{2.b. Komposisi}

Analisis komposisi dilakukan pada setiap elemen pelingkup ruang yang membentuk lapisan secara horizontal. Ditemukan beberapa varian proporsi yang mendefinisikan bentuk fasad dan ruang pada bangunan: 
Tabel 2.

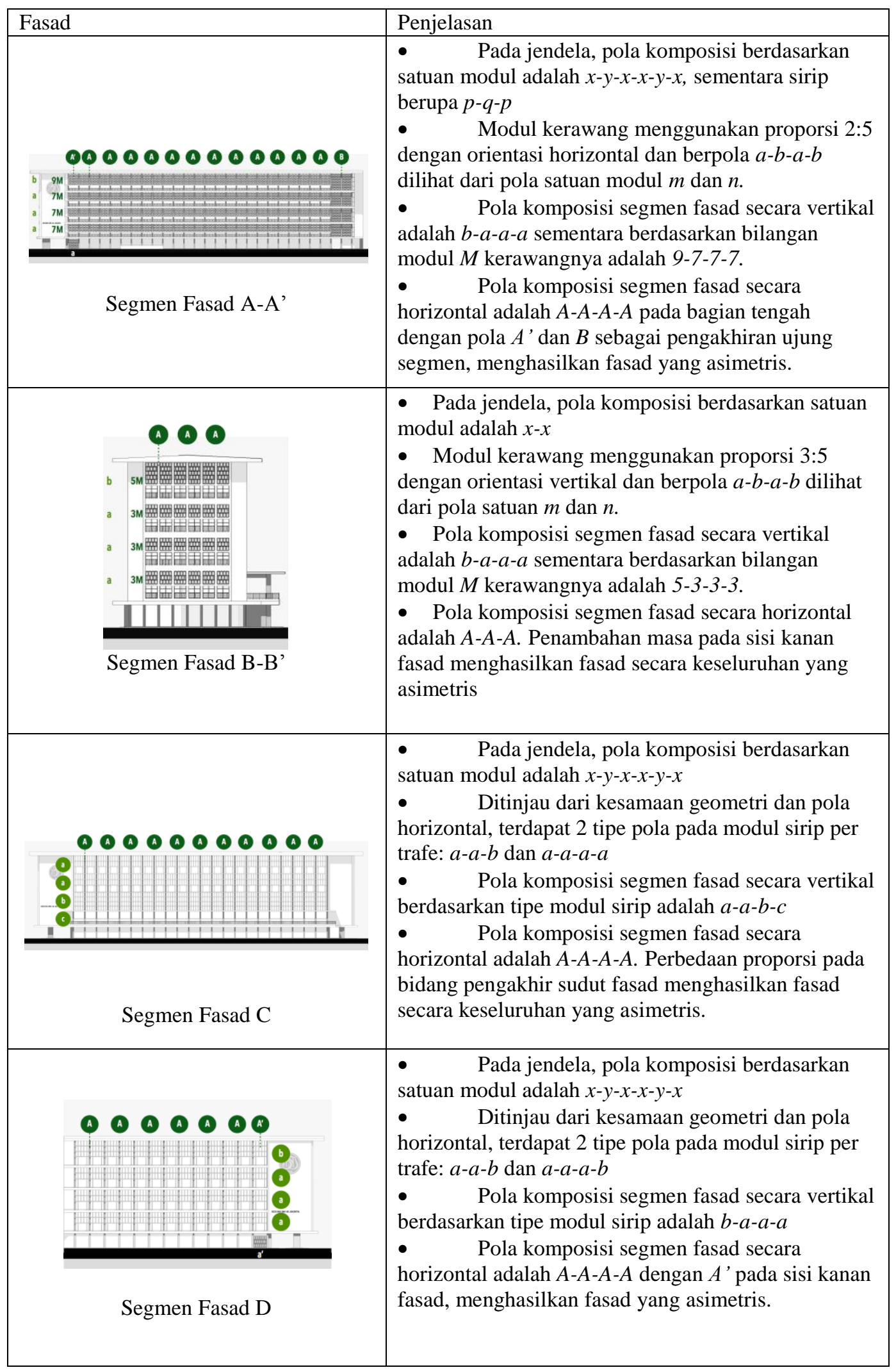




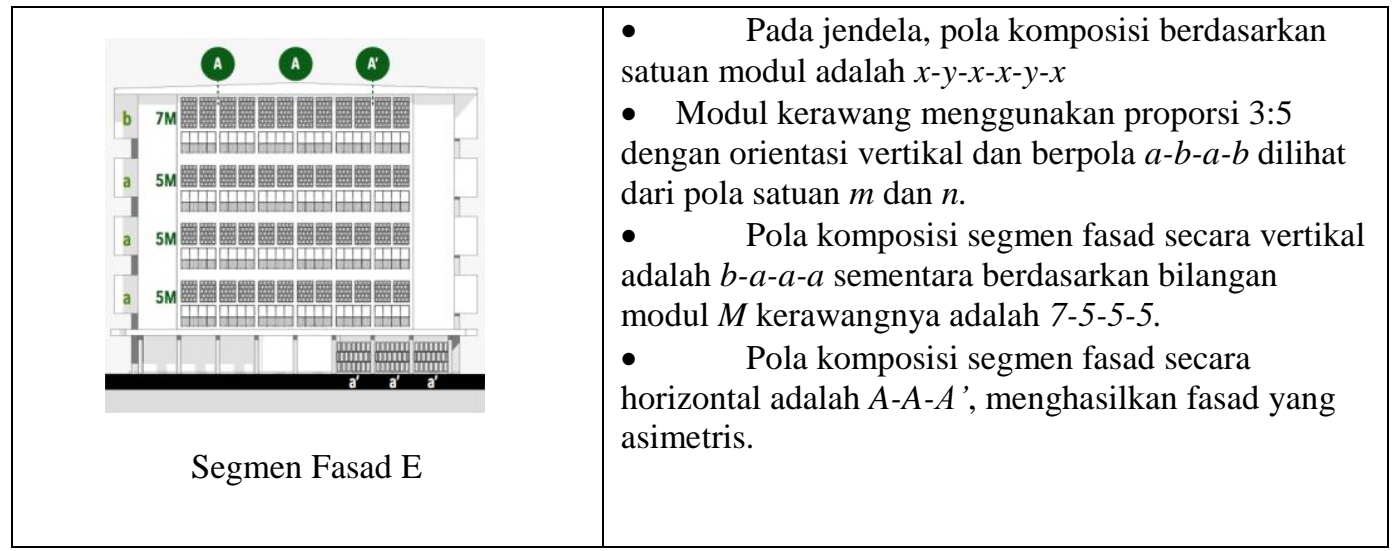

\section{KESIMPULAN}

Hasil analisis pada unsur proporsi menemukan adanya 14 varian proporsi pada seluruh segmen fasad namun ditemukan pula inkonsistensi pada pola penerapannya. Penemuan Golden Section hanya pada salah satu segmen fasad, yaitu pada salah satu tipe modul sirip fasad C, menunjukkan kemungkinan teori proporsi tersebut diterapkan secara tidak sadar sekaligus memperkuat argumen bahwa Golden Section kerap hadir secara alami.

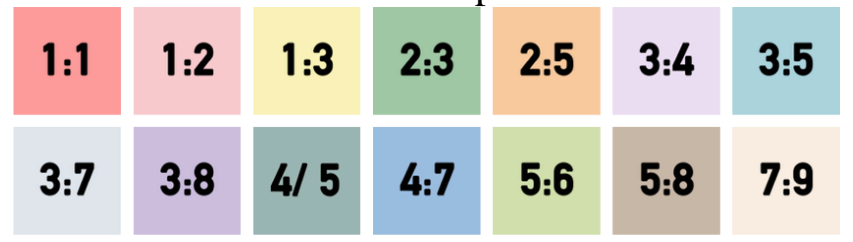

Figur 6. Varian proporsi

Sementara hasil analisis pada unsur komposisi mendapatkan adanya pola hubungan antar elemen dan segmen fasad bangunan. Dimulai dengan modul kerawang sebagai modul terkecil dan yang paling banyak ditemui pada fasad bangunan. Pada modul kerawang, ditemukan suatu pola proporsi dan komposisi yang berulang. Pola komposisi berupa $a-b-a-b$ serta proporsi berdasar angka 5 .

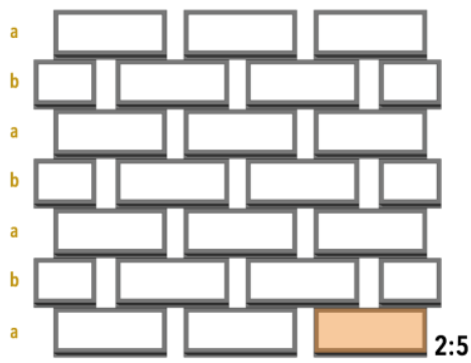

Segmen A-A'

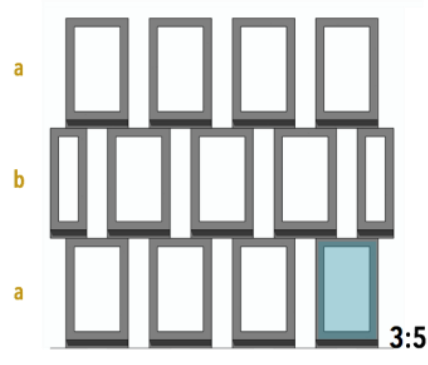

Segmen B

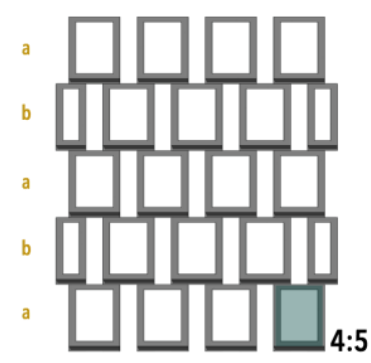

Segmen E

Figur 7. Varian proporsi

Selanjutnya pada segmen fasad, ditemukan suatu pola komposisi yang berulang antar beberapa segmennya. Pola hubungan tersebut dapat dibagi menjadi 3 bagian: yaitu antara segmen fasad E dan B-B', antara segmen fasad A-A' dan B-B', serta antara segmen fasad C dan D'. 
Tabel 3.

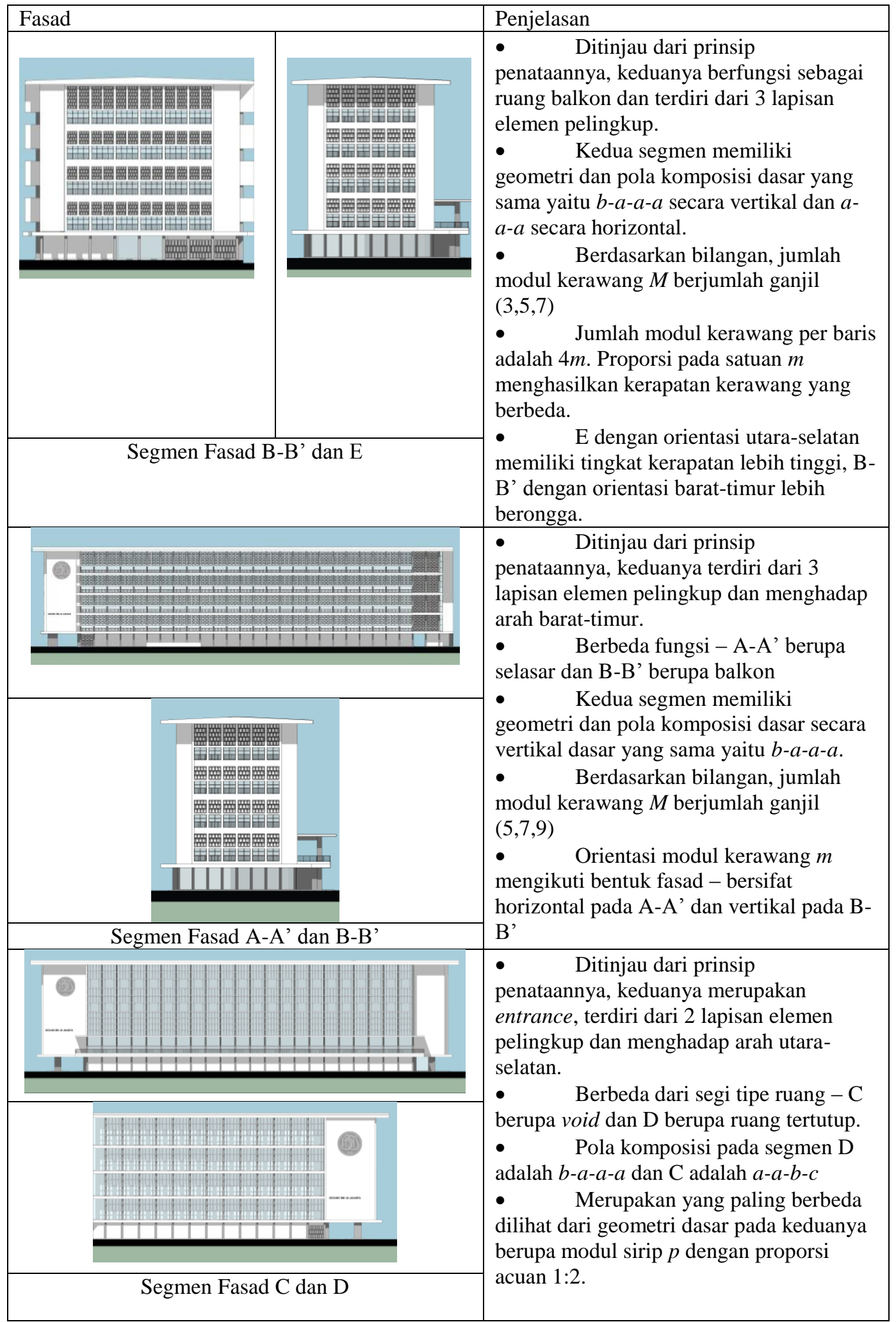

Dari tinjauan pola hubungan yang telah dipaparkan di atas, dapat disimpulkan bahwa hirarki segmen tertinggi terletak pada segmen fasad $\mathrm{C}$ yang menggunakan pola komposisi paling berbeda $(a-a-b-c)$ dan geometri dasar yang juga berbeda. Hal ini mencerminkan fungsi ruang dalamnya yang berupa void area entrance. 
Dari kedua pembahasan analisis, dapat disimpulkan juga bahwa elemen pelingkup jendela kaca dalam hal ini tidak memiliki hubungan dengan elemen pelingkup lainnya baik secara proporsi maupun komposisi. Elemen railing dan ruang padanya dan modul sirip $p$ dapat dikatakan sebagai datum yang menyatukan keseluruhan rancangan.

Selanjutnya kesamaan antar semua segmen fasad terletak pada prinsip penataan fasad yang asimetris. Dengan banyaknya irama atau ritme yang berulang pada bangunan ini, prinsip asimetris menjadi elemen penyeimbang. Di sisi lain, dari banyaknya varian proporsi dan pola komposisi yang ada pada setiap elemen, dapat disimpulkan bahwa kekayaan bentuk geometris dan prinsip visual pada bangunan merupakan salah satu fitur desain Gedung BNI 46 karya Silaban.

\section{DAFTAR PUSTAKA}

(1996). Arsitek dan Karyanya: F. Silaban. Bandung: Nova.

Ching, D.K. (2007). Architecture: Form, Space and Order (3rd edition). New Jersey: John Wiley and Sons.

Elam, Kimberly. (2001). Geometry Of Design: Studies in Proportion and Composition. New York: Princeton Architectural Press.

Evensen, Thomas Thiis. (1987). Archetypes in Architecture. Norwegia University Press. Hanlon, Don. (2009). Composition in Architecture. New Jersey: John Wiley and Sons. Jormakka, Kari. (2007). Basics Design Methods. Basel: Birkhauser.

Kania, Maria Margaretha. (2015). Penerapan Teori Golden Section dan Hukum Fibonachi Terhadap Pembentukan Proporsi Ruang dan Fasad Pada Museum Sandi di Yogyakarta. Bandung: Universitas Katolik Parahyangan.

Salura, Purnama. (2015). Arsitektur yang Membodohkan. Jakarta: Gakushudo Publish.

Satriaji, Kukuh Rizki. (2015). Kajian Estetika Rumah Tinggal Pada Zaman Kolonial Melalui Proporsi Façade Bangunan: Studi Kasus Rumah Tinggal Kawasan Cipunagara. Bandung: Universitas Katolik Parahyangan. 